\title{
A systematic method for DNA fragment amplification and sequencing based on DNA indexing technology. Protocol and technical considerations*
}

\author{
Katarzyna Gromek and Tadeusz Kaczorowski® \\ Laboratory of Extremophiles Biology, Department of Microbiology, Faculty of Biology, University of Gdansk, Gdańsk, Poland
}

DNA indexing is based on a presynthesized library of oligonucleotide adaptors (256 in total), named indexers, and type-IIS restriction endonucleases. It enables amplification and direct analysis of large DNA fragments with low overall redundancy and without subcloning. Here, we describe a detailed protocol for PCR-based amplification of DNA fragments followed by DNA sequencing by indexer walking and provide helpful hints on its practical use. The proposed protocol can be applied to the sequencing of plasmids, cDNA clones, and longer DNA fragments. It can also be used for gap filling at the final stage of genome sequencing projects.

Keywords: PCR; type-IIS restriction endonuclease; oligonucleotide adaptor; DNA sequencing; primer walking

Received: 07 June, 2021; revised: 05 August, 2021; accepted: 05 August, 2021; available on-line: 26 August, 2021

$\square_{\text {e-mail: tadeusz.kaczorowski@ug.edu.pl }}$

*This paper is dedicated to the memory of our Mentor Prof. Waclaw Szybalski whose seminal work on the biology of lambda phage and his creativity in the field of genetic engineering and genomics had opened academic perspectives to many.

Abbreviations: CIP, common indexer primer; TRRM, terminator ready reaction $\mathrm{mix}$

\section{INTRODUCTION}

The present-day DNA research requires fast preparation of templates for sequencing so hundreds of samples can be analyzed simultaneously (Chan, 2005). Problems arise when there is a need to close gaps in big sequencing projects or determine the exact sequence of highly repetitive DNA fragments (Bzymek \& Lovett, 2001). Moreover, research groups that concentrate their work on small plasmid molecules have often used protocols that are widely applied for sequencing of much larger molecules (Lee \& O'Sullivan, 2006). All those issues seemed to be addressed by the introduction of DNA sequencing by primer walking (Strauss et al., 1986). This method allows a very systematic approach to DNA analysis. To be efficient, it requires a rapid synthesis of individually designed primer after every round of DNA sequencing, and the resulting collection of primers may never be used again. Even with considerably low prices of oligonucleotide synthesis, it is still a time-consuming process (Lashkari et al., 1995; Sanghvi \& Schulte, 2004). Several modifications were introduced to limit the amount of once-used primers, like the application of short oligonucleotides that formed full-length primer during the annealing step (Szybalski, 1990; Kieleczawa et al., 1992; Kaczorowski \& Szybalski, 1994). Still, the libraries created of 5 - or 6-mers are challenging to handle, and the process of primer formation is not easily adapted to the modern sequencing chemistry (Lohdi \& McCombie, 1996; Raja et al., 1997; Kaczorowski \& Szybalski, 1996a; Kaczorowski \& Szybalski 1996b). In 1990 it was proposed to use a short double-stranded oligonucleotide adaptor (called an oligo-cassette) to sequence fragments adjacent to the already known genomic DNA (Rosenthal and Jones, 1990). The subsequent development allowed to retrieve unknown DNA fragments obtained by digest with type-IIS restriction endonucleases without any cloning and was based on ligation of two oligonucleotide adaptors, the so-called indexers (Fig. 1), chosen from a presynthesized library (Unrau \& Deugau, 1994; Szybalski et al., 1991). With the idea of "the universal restriction enzyme," Prof. Waclaw Szybalski pioneered the use of type-IIS restriction endonucleases as tools in DNA processing which resulted in the development of many ingenious laboratory techniques (Szybalski, 1985; Podhajska \& Szybalski, 1985; Hasan et al., 1986; Posfai \& Szybalski, 1988; Velculescu et al., 1995). This has also started a long interest of Prof. Anna J. Podhajska laboratory (University of Gdansk, Poland) in biochemistry of shifters with special focus on FokI (Kaczorowski et al., 1989; Skowron et al., 1993; Kaczorowski et al., 1999), MboII (Sektas et al., 1992; Sektas et al., 1995; FurmanekBlaszk et al., 2009), and MmeI enzymes (Tucholski et al., 1998; Nakonieczna et al., 2009).

Our laboratory applied the DNA indexing method to sequence unknown DNA molecules in a highly systematic mode. We called it DNA sequencing by indexer walking (Gromek \& Kaczorowski, 2005). The idea was conceived during a stay in Prof. Waclaw Szybalski's laboratory at the University of Wisconsin-Madison. The basic outline for the method of DNA sequencing by indexer walking can be best summarized by four steps: cloning

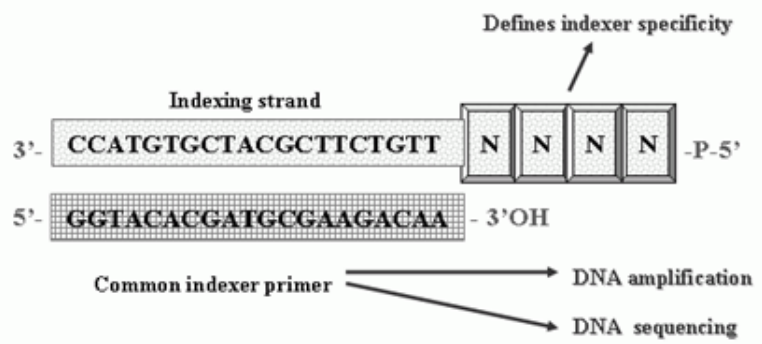

Figure 1. Schematic presentation of indexer structure.

The common indexer primer (20-mer) is annealed to a longer oligonucleotide (24-mer) that defines the double-stranded indexer's specificity. Each indexing strand has a unique four-nucleotide long 5 '-protruding end and is a part of the library of 256 oligonucleotides. 


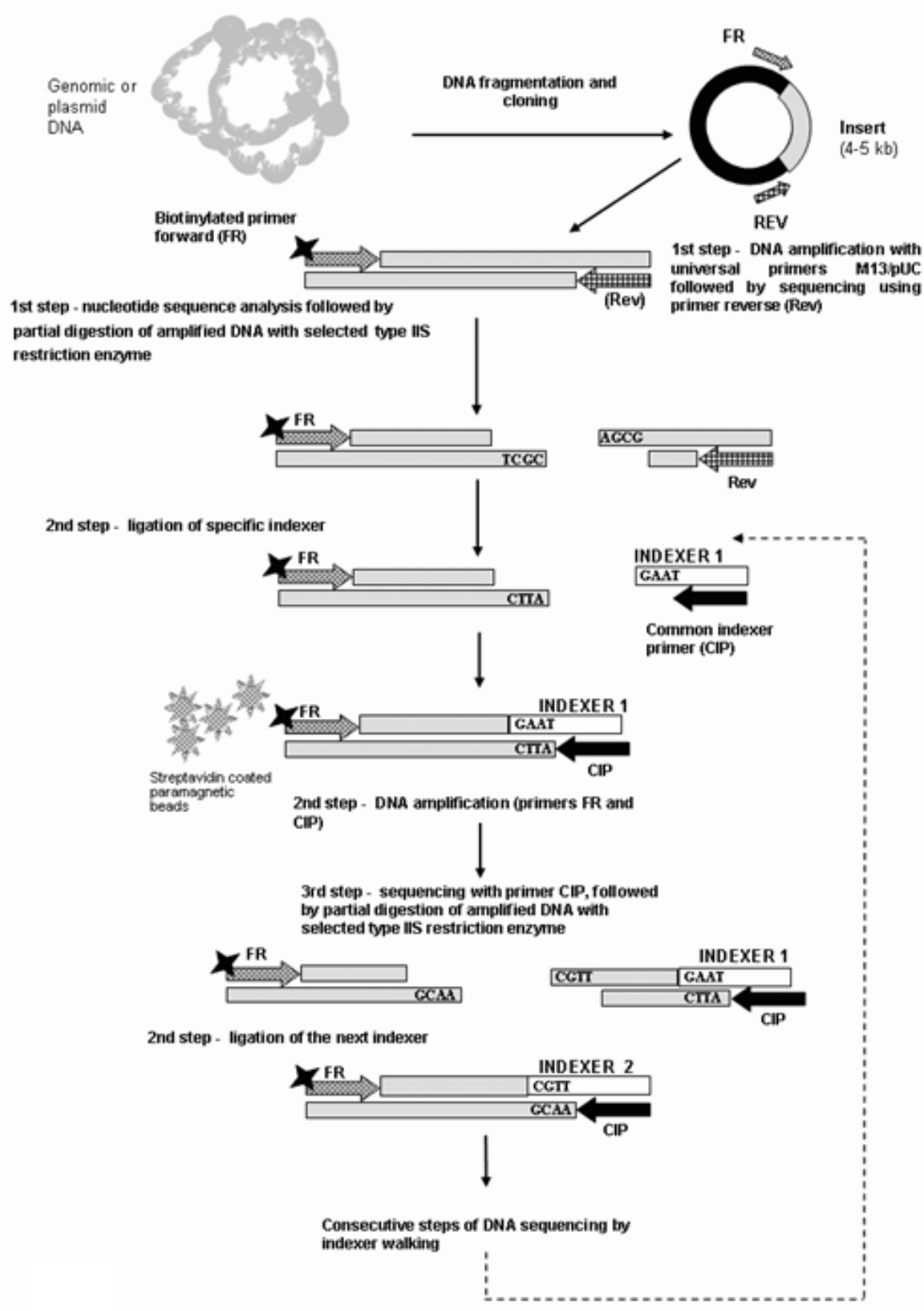

Figure 2. Schematic representation of DNA sequencing by indexer walking.

Source: Figure modified from Gromek and Kaczorowski (2005). The protocol of DNA sequencing by indexer walking incorporates efficient ligation of double-stranded synthetic oligonucleotides (indexers) to DNA fragments produced by class IIS restriction endonucleases which generate four nucleotide long $5^{\prime}$ protruding ends, and their subsequent amplification, which provides enough template for automated DNA sequencing. Data gathered in the first sequencing reaction permits further movement into the unknown DNA sequence by digestion with class IIS restriction endonuclease followed by ligation of the next indexer. The presynthesized library of indexers (256 oligonucleotides) enables bi-directional analysis of any DNA molecule and provides universal primers for sequencing.

unknown DNA fragment into a suitable vector, the first step of DNA amplification, sequencing, and analysis followed by a second step consisting of indexer ligation to DNA template and amplification, and finalized with a third step - DNA sequencing and analysis (Fig. 2). The second and third steps are repeated until the whole sequence of the DNA fragment is determined. Then, the process is repeated for the complementary DNA strand. During initial testing of this method, we concentrated on sequencing small plasmids up to $5-\mathrm{kb}$. Still, with the discovery of more robust thermostable DNA polymerases and variations introduced by the enzyme manufac- tures, the initial unknown fragment can be longer (Lee et al., 2007; Cline et al., 1996). The key element of this method, the double-stranded indexer, is formed by annealing a universal indexing primer (CIP) to one of the 256 longer oligonucleotides, which differ only by 4-nt at the 5'-end (Fig. 1). The small library of 256 indexers, with low prices of oligo synthesis and with the minimal amount used per one ligation reaction (100 fmol of indexer), is more than affordable. It is also universal because it can be used for any DNA sequencing project. The type-IIS restriction endonucleases used for systematic trimming of DNA molecules digest DNA leaving 4-nt 
5'-overhangs that are then matched to adaptors from our library (Table 1). Many manufacturers sell these enzymes, and several enzymes with new specificities might be commercially available in the future (http://rebase. neb.com). Now we present a very detailed protocol for DNA sequencing by indexer walking.

\section{MATERIALS AND METHODS}

\section{Reagents}

R.1. Phosphorylation of 5'-Terminus of the Indexing Strands

1) $10 \times \mathrm{T} 4$ polynucleotide kinase buffer (PNK) (New England Biolabs, USA): $700 \mathrm{mM}$ Tris-HCl, pH 7.6, $100 \mathrm{mM} \mathrm{MgCl}, 50 \mathrm{mM}$ dithiothreitol.

2) $10 \mathrm{mM}$ ATP.

3) T4 polynucleotide kinase (New England Biolabs,

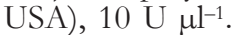

4) 1 nmol 24-mer indexing strand oligonucleotide (1 $\mathrm{nmol} \mu \mathrm{l}^{-1}$ ).

\section{R.2. Indexer Assembly}

1) $1 \times$ T4 DNA ligase buffer with no ATP added (Epicentre, USA): $33 \mathrm{mM}$ Tris-acetate, $\mathrm{pH}$ 7.8, $66 \mathrm{mM}$ potassium acetate, $10 \mathrm{mM}$ magnesium acetate, $0.5 \mathrm{mM}$ dithithreitol.

2) Phosphorylated indexing strand oligonucleotide (500 pmol).

3) Short (20-mer) universal primer oligonucleotide (500 pmol).

\section{R.3. Plasmid DNA Purification}

1) $25 \mathrm{mM}$ Tris- $\mathrm{HCl} \mathrm{pH}$ 8.0, $50 \mathrm{mM}$ glucose, $10 \mathrm{mM}$ EDTA.

2) $0.2 \mathrm{M} \mathrm{NaOH}, 10 \% \mathrm{SDS}$.

3) Phenol, equilibrated with $0.1 \mathrm{M}$ Tris- $\mathrm{HCl}, \mathrm{pH} 8.0$

4) Chloroform

5) $3 \mathrm{M}$ potassium acetate, $\mathrm{pH} 4.8$

6) $96 \%$ ethanol, $70 \%$ ethanol,

7) $0.1 \times$ Tris-EDTA buffer, $\mathrm{pH} 8.0(10 \mathrm{mM}$ Tris- $\mathrm{HCl}$, $\mathrm{pH}$ 8.0, 1 mM EDTA)

R.4. Cloning DNA into Vectors to Obtain Library of Inserts of up to 5 -kb in Length

1) DNA restriction fragment or plasmid of interest linearized with restriction nuclease.

2) Linearized vector DNA with matching ends.

3) 1 T4 DNA ligase buffer with ATP (Epicentre, USA): $33 \mathrm{mM}$ Tris-acetate, $\mathrm{pH} 7.8,66 \mathrm{mM}$ potassium acetate, $10 \mathrm{mM}$ magnesium acetate, $0.5 \mathrm{mM}$ dithiothreitol, $1 \mathrm{mM}$ ATP.

4) T4 DNA ligase (Epicentre, USA), $10 \mathrm{U}_{\mu \mathrm{l}^{-1}}$.

R.5. Partial Digestion of DNA with Type-IIS Restriction Endonucleases

1) Appropriate type-IIS restriction endonuclease, $2 \mathrm{U}_{\mu \mathrm{l}^{-1}}$

2) $10 \times$ restriction enzyme buffer recommended by the manufacturer.

3) 300 ng template DNA.

4) Clean-Up spin columns (A\&A Biotechnology, Poland).

5) $0.1 \times$ Tris- EDTA buffer $(1 \mathrm{mM}$ Tris- $\mathrm{HCl}, \mathrm{pH} 8.0$, $0.1 \mathrm{mM}$ EDTA).

\section{R.6. Indexer Ligation}

Ligation reaction: $1 \times$ T4 DNA ligase buffer with ATP (33 mM Tris-acetate, $\mathrm{pH} 7.8,66 \mathrm{mM}$ potassium acetate, $10 \mathrm{mM}$ magnesium acetate, $0.5 \mathrm{mM}$ dithiothreitol, $1 \mathrm{mM}$ ATP), highly concentrated T4 DNA ligase (Epicentre,

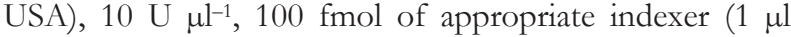
of $100 \mathrm{fmol}$ working concentration solution), $60 \mathrm{ng}$ of DNA fragment.

\section{R.7. Individual PCR Reactions}

1) $10 \times$ PCR buffer $(100 \mathrm{mM}$ Tris- $\mathrm{HCl}, \mathrm{pH} 8.8$, $15 \mathrm{mM} \mathrm{MgCl}_{2}, 500 \mathrm{mM} \mathrm{KCl}, 10 \mathrm{mM}$ Triton X-100).

2) $0.8 \mathrm{mM}$ dNTPs.

3) $5 \mathrm{M}$ betaine.

4) 50 or 25 pmol of primers (common indexer primer or universal vector primer).

5) DyNAzyme II DNA polymerase (Finzyme, Fin-

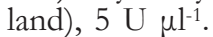

6) $P f u$ polymerase (Thermo Scientific, USA), $0.35 \mathrm{U}_{\mu \mathrm{l}^{-1}}$.

R.8. Gel Electrophoresis and PCR Product Extraction

1) $1 \%$ agarose gel with ethidium bromide $\left(0.5 \mu \mathrm{g} \mathrm{ml} \mathrm{m}^{-1}\right)$.

2) DNA purification Kit Gel Out (A\&A Biotechnology, Poland).

\section{R.9. DNA Sequencing.}

1) Terminator Ready Reaction Mix (TRRM) with AmpliTaq DNA polymerase (Perkin Elmer, Applied Biosystems, USA).

2) $5 \times$ Sequencing buffer (Perkin Elmer, Applied Biosystems, USA): $400 \mathrm{mM}$ Tris- $\mathrm{HCl}, 10 \mathrm{mM} \mathrm{MgCl}_{2}, \mathrm{pH}$ 9.0 .

3) 3.4 pmol of primer (M13/pUC forward/reverse or common indexer primer).

4) TSR reagent (Perkin Elmer, Applied Biosystems, USA).

5) ExTerminator spin column (A\&A Biotechnology, Poland).

\section{R.10. DNA Analysis}

1) Vector NTI (Informax, USA).

2) One-Dscan (Scanalytics, USA).

\section{Protocol}

\section{P.1. Phosphorylation of 5'-Terminus of the Indexing Strands}

Indexing strands are phosphorylated at the 5'-terminus to make them suitable for ligation to DNA fragments produced by type-IIS restriction endonucleases.

1) Mix $1 \mu \mathrm{l}$ of $10 \times$ T4 PNK buffer, $1 \mu \mathrm{l} 10 \mathrm{mM}$ ATP, $1 \mu \mathrm{l}$ T4 polynucleotide kinase, and $1 \mu$ l of indexing strand oligonucleotide ( 1 nmole) in a total reaction mixture volume of $10 \mu \mathrm{l}$.

2) Incubate at $37^{\circ} \mathrm{C}$ for $30 \mathrm{~min}$.

3) Stop the reaction by heating at $80^{\circ} \mathrm{C}$ for $2 \mathrm{~min}$.

4) Allow to cool to room temperature $\left(\mathrm{RT}-20^{\circ} \mathrm{C}\right)$.

5) Can be stored at $-20^{\circ} \mathrm{C}$.

\section{P.2. Indexer Assembly}

1) Double-stranded indexers (Fig. 1) are prepared in $10 \mu$ volume of $1 \times$ T4 DNA ligase buffer with no ATP by annealing a 20-mer common indexer primer (500 pmoles) to 1 of the 256 individually synthesized 24-mer indexer strands (phosphorylated) (500 pmoles). 
2) Heat at $65^{\circ} \mathrm{C}$ for $5 \mathrm{~min}$ and then allow to cool slowly to room temperature.

3) Dilute indexer solution to working concentration of $100 \mathrm{fmol}$ with $1 \times \mathrm{T} 4$ ligase buffer and store at $-20^{\circ} \mathrm{C}$.

\section{P.3. Plasmid DNA purification}

1) Isolate plasmid DNA by the alkaline lysis method (Sambrook et al., 1989).

2) Calculate plasmid DNA concentration using NanoDrop 1000 UV-Vis spectrophotometer (Thermo Fisher Scientific). We also found that the One-Dscan ver. 1.33 software (Scanalytics, USA) works well for measuring DNA concentration against known standards. The choice of technique depends on equipment and software available for use in a given laboratory.

P.4. Cloning DNA of Interest into Vectors to Obtain Library of Inserts up to $5-\mathrm{kb}$ in Length

We use the pGEM3Zf(+) vector (Promega, USA) as our primary choice because of high DNA yields, the wide selection of restriction enzymes for cloning, and the ability to use the universal primers $\mathrm{M} 3 / \mathrm{pUC}$, Forward (-23) 5'-GTTGTAAAACGACGGCCAGT, and Reverse (-28) 5'-CACAGGAAACAGCTATGACC.

1) Mix $1 \mu \mathrm{l}$ T4 DNA ligase, $20 \mathrm{ng}$ of linearized vector DNA, and $100 \mathrm{ng}$ of target DNA (linearized natural plasmid or DNA fragment processed with restriction enzymes) in $10 \mu \mathrm{l}$ total volume of $1 \times \mathrm{T} 4 \mathrm{DNA}$ ligase buffer with ATP.

2) Incubate at room temperature for $2 \mathrm{hr}$.

3) Introduce ligated DNA molecules into bacterial cells by transformation or electroporation.

4) Screen for recombinant clones.

5) Purify plasmid DNA according to step P.3.

\section{P.5. 1st Step - DNA Amplification and Sequencing}

Amplify cloned DNA fragment by use of universal vector primers which flank the cloned insert. This step provides a DNA template for the next round of DNA analysis and processing.

1) Mix $60 \mathrm{ng}$ of cloned plasmid DNA, $50 \mathrm{pmol}$ of universal vector primers, and $0.8 \mathrm{mM}$ dNTPs in a total volume of $50 \mu \mathrm{l} 1 \times$ PCR buffer.

2) Incubate at $94^{\circ} \mathrm{C}$ for $2 \mathrm{~min}$.

3) Add a mixture of two thermostable DNA polymerases (4 U DyNAzyme II DNA polymerase, Finzymes, and $0.2 \mathrm{U}$ of $P f u$ DNA polymerase, Thermo Scientific).

4) Preheat at $94^{\circ} \mathrm{C}, 2 \mathrm{~min}$, and then cycle 30 times at $94^{\circ} \mathrm{C}, 40 \mathrm{~s}$, at $55-61^{\circ} \mathrm{C}, 40 \mathrm{~s}$, and $72^{\circ} \mathrm{C}, 4-9 \mathrm{~min}$.

5) Follow by additional extension step at $72^{\circ} \mathrm{C}, 10$ min, and hold at $4^{\circ} \mathrm{C}$ as needed.

The melting temperature of both primers determines the annealing temperature, and the extension time should be adequate to the length of the amplified DNA fragment

6) Purify by isolating from 1\% agarose gel after electrophoresis separation $(2 \mathrm{~h}, 40 \mathrm{~mA})$.

7) Calculate DNA concentration.

First round of DNA sequencing is performed with one of the universal vector primers (forward or reverse).

8) Mix $200 \mathrm{ng}$ of amplified DNA, 3.4 pmol universal vector primer, $3 \mu$ l TRRM (Terminator Ready Reaction Mix) and $3 \mu \mathrm{l} 5 \times$ sequencing buffer in a total volume of $20 \mu \mathrm{l}$.

9) Cycle 35 times at $96^{\circ} \mathrm{C}, 30 \mathrm{~s}$, at $51^{\circ} \mathrm{C}, 20 \mathrm{~s}$, and $60^{\circ} \mathrm{C}, 4 \mathrm{~min}$. Hold at $4^{\circ} \mathrm{C}$ as needed.
10) Separate extension reaction products by use of ExTerminator spin columns according to the manufacturer's manual.

11) Denature purified extension product by heating at $95^{\circ} \mathrm{C}$ for $5 \mathrm{~min}$ and fast cooling on ice for at least 2 $\min$.

12) Separate sequencing reaction products on an $A B I$ PRISM 310 Genetic Analyzer (Perkin Elmer, Applied Biosystems, USA) equipped with a 60-cm capillary filled with POP6 polymer, for $150 \mathrm{~min}$ under standard running conditions.

\section{P.6. 1st Step - DNA Analysis and Partial Digestion}

The purpose of this step is to shorten the amplified DNA molecule by $450-500$ bp from either side to obtain fragments with 4-nt nonidentical 5'-overhangs.

1) Analyze the obtained DNA sequence using software (Vector NTI) to find restriction sites recognized by type-IIS restriction endonucleases.

2) Partially digest $300 \mathrm{ng}$ of an amplified DNA fragment with $2 \mathrm{U}$ of appropriate type-IIS restriction endonuclease in a total volume of $20 \mu \mathrm{l}$ of $1 \times$ restriction enzyme buffer for $15 \mathrm{~min}$. The incubation temperature depends on the properties of restriction endonucleases and is suggested by the enzyme manufacturer.

3) Inactivate enzymes by heating at the recommended temperature for $20 \mathrm{~min}$.

4) Elute DNA fragment on Clean-Up spin columns with $20 \mu \mathrm{l} 0.1 \times$ Tris-EDTA buffer $(10 \mathrm{mM}$ Tris-HCl, 1 mM EDTA, pH 8.0).

Alternatively, DNA can be extracted with phenolchloroform, precipitated with ethanol, and finally dissolved in $10 \mu \mathrm{l} 0.1 \times$ Tris-EDTA pH 8.0 buffer.

\section{P.7. 2nd Step - DNA Indexing and Amplification}

Partially digested DNA is the template for attaching a double-stranded indexer with complementary 4-nt 5'-protruding end, followed by amplification with one universal vector primer and an indexer-specific primer.

1) Perform ligation reaction in $10 \mu \mathrm{l}$ of $1 \times \mathrm{T} 4 \mathrm{DNA}$ ligase buffer with ATP by mixing $60 \mathrm{ng}$ of partially digested DNA, $10 \mathrm{U}$ of T4 DNA ligase, and $100 \mathrm{fmol}$ of the appropriate indexer.

2) Incubate at room temperature for $1 \mathrm{hr}$.

3) Inactivate the enzyme by heating at $65^{\circ} \mathrm{C}$ for $10 \mathrm{~min}$.

4) Prepare PCR mix by adding $12 \mathrm{ng}$ of indexed DNA, 25 pmol primers (universal vector primer and a common indexer primer), $0.8 \mathrm{mM}$ dNTPs, and $10 \mu \mathrm{l}$ betaine to a total volume of $50 \mu \mathrm{l} 1 \times$ PCR buffer.

5) Incubate at $94^{\circ} \mathrm{C}$ for $2 \mathrm{~min}$.

6) Add the mixture of two thermostable DNA polymerases (4 U DyNAzyme II DNA polymerase, Finzymes, and $0.2 \mathrm{U}$ of Pfu DNA polymerase, Thermo Scientific).

7) Preheat at $94^{\circ} \mathrm{C}, 2 \mathrm{~min}$, and then cycle 30 times at $94^{\circ} \mathrm{C}, 40 \mathrm{~s}$, at $55-61^{\circ} \mathrm{C}, 40 \mathrm{~s}$, and $72^{\circ} \mathrm{C}$.

8) Follow by additional extension step at $72^{\circ} \mathrm{C}$, $10 \mathrm{~min}$, and hold at $4^{\circ} \mathrm{C}$ as needed.

The time for the extension step depends on the length of the DNA template.

9) Purify DNA fragment by isolating from $1 \%$ agarose gel after electrophoresis separation $(2 \mathrm{~h}, 40 \mathrm{~mA})$.

10) Calculate DNA concentration.

\section{P.8. 3rd Step - DNA Sequencing, Analysis, and Partial Digestion}

The amplified DNA fragment, flanked both by the universal vector primer sequence and attached indexer, 
Table 1. Commercially available type IIS restriction endonucleases (http://rebase.neb.com).

\begin{tabular}{|c|c|c|}
\hline Type-IIS restriction endonuclease & Recognition sequence (digest site) & Average length of generated fragments (bp) \\
\hline Aarl, PaqCl & CACCTGC(4/8) & 8192 \\
\hline Alw26l, BsmAl, BcoDI, BstMAl & $\operatorname{GTCTC}(1 / 5)$ & 512 \\
\hline Bbsl, Bpil, BpuAl, BstV2I & GAAGAC $(2 / 6)$ & 2024 \\
\hline Bbvl, BseXI, BstV1I, Lsp1109I & GCAGC(8/12) & 512 \\
\hline BsIFI, BpuSI, BsmFI, Faql & GGGAC(10/14) & 512 \\
\hline BspMI, Bvel, BfuAl, Acc36l & ACCTGC(4/8) & 2024 \\
\hline BtgZI & GCGATG(10/14) & 2024 \\
\hline Bsal, BspTNI, Eco31I & GGTCTC(1/5) & 2024 \\
\hline Esp3I, BsmBI & CGTCTC(1/5) & 2024 \\
\hline Fokl & GGATG(9/13) & 512 \\
\hline Bmsl, Lwel, SfaNI & GCATC(5/9) & 512 \\
\hline
\end{tabular}

is a substrate for further analysis. DNA sequencing reaction is performed with the use of the common indexer primer.

1) Mix $200 \mathrm{ng}$ of amplified DNA, $3.4 \mathrm{pmol}$ common indexer primer, $3 \mu \mathrm{l}$ TRRM and $3 \mu \mathrm{l} 5 \times$ sequencing buffer in a total volume of $20 \mu \mathrm{l}$.

2) Cycle 35 times at $96^{\circ} \mathrm{C}, 30 \mathrm{~s}$, at $51^{\circ} \mathrm{C}, 20 \mathrm{~s}$, and $60^{\circ} \mathrm{C}, 4 \mathrm{~min}$. Hold at $4^{\circ} \mathrm{C}$ as needed.

3) Separate extension reaction products by use of ExTerminator spin columns according to the manufacturer's manual.

4) Denature purified extension product by heating at $95^{\circ} \mathrm{C}$ for $5 \mathrm{~min}$ and fast cooling on ice for at least 2 min.

5) Separate sequencing reaction products on an $\mathrm{ABI}$ PRISM 310 Genetic Analyzer (Perkin Elmer, Applied Biosystems, USA) equipped with a $60-\mathrm{cm}$ capillary filled with POP6 polymer, for $150 \mathrm{~min}$ under standard running conditions.

6) Analyze obtained DNA sequence to find restriction sites recognized by type-IIS restriction endonucleases.

7) Partially digest $300 \mathrm{ng}$ of an amplified DNA fragment with $2 \mathrm{U}$ of appropriate type-IIS restriction endonucleases in a total volume of $20 \mu \mathrm{l} 1 \times$ restriction enzyme buffer for $15 \mathrm{~min}$. The incubation temperature depends on the properties of restriction endonucleases and is suggested by the enzyme manufacturer.
8) Inactivate enzymes by heating at the recommended temperature for $20 \mathrm{~min}$.

9) Elute DNA on Clean-Up spin columns with $20 \mu \mathrm{l}$ $0.1 \times$ Tris-EDTA pH 8.0 buffer.

Alternatively, DNA can be extracted with phenolchloroform, precipitated with ethanol, and finally dissolved in $10 \mu \mathrm{l}$ of $0.1 \times$ Tris-EDTA pH 8.0 buffer.

\section{P.9. Consecutive Cycles of $2^{\text {nd }}$ and $3^{\text {rd }}$ Step}

Follow with cycles of the $2^{\text {nd }}$ and $3^{\text {rd }}$ step until the complete sequence of the analyzed DNA fragment is determined. Then, to obtain the second DNA strand sequence, follow the whole procedure (point P.5.8 to P.8) using the second universal vector primer.

\section{COMMENTS}

In testing DNA sequencing by indexer walking, we introduced several modifications and improvements to ameliorate the overall performance for this method.

1. Oligonucleotides used in this protocol are in a desalted form and are applied without any purification procedure.

2. The sequence of our CIP oligonucleotide is as follows: 5'- TAC ACT GGC TGC GTA TCT GG 3'. Table 2 presents the indexing strands used for sequencing of the pEC278 plasmid (GenBank accession no.

Table 2. Indexers and type-IIS restriction endonucleases used to sequence the pEC278 plasmid. The cut sites relate to DNA sequence of pEC278 (GenBank accession no. AY589571).

\begin{tabular}{|c|c|c|c|c|c|}
\hline \multicolumn{3}{|c|}{ Leading strand } & \multicolumn{3}{|c|}{ Complementary strand } \\
\hline Number & Indexer & Enzyme and cut site & Number & Indexer & Enzyme and cut site \\
\hline Ind1 & 5'ATCT & SfaNI (542) & Ind11 & 5'AGTA & Bbsl (4439) \\
\hline Ind2 & 5'GTGA & Fok (794) & Ind12 & 5'AGCT & HindIII (3975) \\
\hline Ind3 & 5'GATC & Fokl $(1310)$ & Ind13 & 5'TATT & Fokl (3505) \\
\hline Ind4 & $5^{\prime}$ CCGA & SfaNI (1709) & Ind14 & 5'ATGC & Fokl $(3010)$ \\
\hline Ind5 & 5'CAGG & Bbvl (2241) & Ind15 & 5'AGCG & Bbvl (2665) \\
\hline Ind6 & $5^{\prime} \mathrm{CGCT}$ & Bbvl (2668) & Ind16 & 5'GAAT & Fokl (2132) \\
\hline Ind7 & 5'AAAT & Bbvl (2895) & Ind17 & 5'CTGG & SfaNI (1706) \\
\hline Ind8 & 5'TAAC & SfaNI (3360) & Ind18 & 5'GATC & Fokl (1307) \\
\hline Ind9 & 5'AGCT & HindIII (3978) & Ind19 & 5'GACT & Bbvl (852) \\
\hline Ind10 & 5'ТACT & Bbsl (4442) & Ind20 & $5^{\prime} \mathrm{AGAT}$ & SfaNl (539) \\
\hline
\end{tabular}


AY589571). This 4669 bp plasmid was sequenced with the use of 20 indexers for both strands.

3. NanoDrop 1000 UV-Vis spectrophotometer (Thermo Fisher Scientific) is used to measure DNA concentration.

4. At present, there are 31 commercially available typeIIS restriction endonucleases that recognize 11 unique recognition sequences $5-7 \mathrm{bp}$ in length (Table 1). The average size of the fragment produced ranges from 512 to $8196 \mathrm{bp}$. In the absence of any appropriate type-IIS restriction enzyme, it is possible to use regular type-II restriction enzymes that rarely cut the already sequenced DNA fragment. We have successfully employed this approach in sequencing the pEC278 plasmid (Gromek \& Kaczorowski, 2005; GenBank accession no. AY589571). For the 3900-4000 region, the only enzyme of choice (a rare cutter) was HindIII. The same enzyme was used in determining the sequence of the corresponding region on the complementary strand.

5. For increased amplification specificity, it is possible to use a biotinylated universal

vector primer in every amplification reaction. The biotin residue is attached to the 5'-end of the universal vector primer. The following protocol is optional:

a) After ligation of indexer to the DNA target, recover biotinylated indexed DNA by mixing $5 \mu \mathrm{l}$ of the ligation mixture with $40 \mu \mathrm{l}$ of $1 \times$ saline washed streptavidin-coated beads (Streptavidin MagnaSphere Paramagnetic Particles, Promega, USA). Recently, we found that the addition of recombinases can improve the specificity of PCR-based DNA amplification (Stefanska et al., 2014; Stefanska et al., 2016).

b) Isolate the DNA molecules with a newly attached indexer from the ligation mix by magnetic separation stand (Promega, USA). Incubate at room temperature for $5-10 \mathrm{~min}$.

c) Wash twice with $2 \times$ Binding and Washing solution (10 mM Tris-HCl, pH 7.5; 1 mM EDTA; $2 \mathrm{M} \mathrm{NaCl}$ ).

d) Suspend beads with attached DNA in $20 \mu \mathrm{l}$ of 10 mM Tris- $\mathrm{HCl}, \mathrm{pH}$ 8.0.

e) Use $5 \mu \mathrm{l}$ of suspended beads with attached DNA as a template in PCR amplification.

6. In parallel to standard procedure for isolation of DNA fragments from agarose gels, we developed a higly efficient protocol for electrophoretic transfer of DNA from a gel to DEAE-cellulose membrane (Kaczorowski et al., 1993).

7. The manufacturer of Terminator Ready Reaction Mix (TRRM) with AmpliTaq DNA polymerase (Perkin Elmer, Applied Biosystems, USA) used for sequencing recommends applying $8 \mu \mathrm{l}$ TRRM per reaction. We found that using less TRRM and adding $5 \times$ Sequencing Buffer (also supplied by the same company) gave better resolution. The capillary injection time for the ABI Prism 310 Genetic Analyzer was in the range of 20 to $60 \mathrm{~s}$ depending on the quality of DNA used in sequencing reactions.

\section{REFERENCES}

Bzymek M, Lovett ST (2001) Instability of repetitive DNA sequences: The role of replication in multiple mechanisms. Proc Natl Acad Sci U S A 98: 8319-8325. https://doi.org/10.1073/pnas.111008398

Chan EY (2005) Advances in sequencing technology. Mutat Res 573: 13-40. https://doi.org/10.1016/j.mrfmmm.2005.01.004

Cline J, Braman JC, Hogrefe HH (1996) PCR fidelity of Pfu DNA polymerase and other thermostable DNA polymerases. Nucl Acids Res 24: 3546-3551. https://doi.org/10.1093/nar/24.18.3546

Furmanek-Blaszk B, Boratynski R, Zolcinska N, Sektas M (2009) M1.MboII and M2.MboII type-IIS methyltransferases: different spe- cificities, the same target. Microbiology 155: 1111-1121. https://doi. org/10.1099/mic.0.025023-0

Gromek K, Kaczorowski T (2005) DNA sequencing by indexer walking. Clin Chem 51: 1612-1618. https://doi.org/10.1373/ clinchem.2004.046599

Hasan N, Kim SC, Podhajska AJ, Szybalski W (1986) A novel multistep method for generating precise unidirectional deletions using BspMI, a class-IIS restriction enzyme. Gene 50: 55-62. https://doi. org/10.1016/0378-1119(86)90309-4

Kaczorowski T, Sektas M, Furmanek B (1993) An improvement in electrophoretic transfer of DNA from a gel to DEAE-cellulose membrane. Biotechniques 14: 900

Kaczorowski T, Skowron P, Podhajska AJ (1989) Purification and characterization of the FokI restriction endonuclease. Gene 80: 209216. https://doi.org/10.1016/0378-1119(89)90285-0

Kaczorowski T, Sektas M, Skowron P, Podhajska AJ (1999) The FokI methyltransferase from Flavobacterium okeanokoites. Purification and characterization of the enzyme and its truncated derivatives. Mol Biotechnol 13: 1-15. https://doi.org/10.1385/MB:13:1:1

Kaczorowski T, Szybalski W (1994) Assembly of 18-nucleotide primers by ligation of three hexamers: sequencing of large genomes by primer walking. Anal Biochem 221: 127-135. https://doi. org/10.1006/abio.1994.1388

Kaczorowski T, Szybalski W (1996a) Cooperativity of hexamer ligation. Gene 179: 189-193. https://doi.org/10.1016/s0378-1119(96)00324-1

Kaczorowski T, Szybalski W (1996b) Automated four-color DNA sequencing using primers assembled by hexamer ligation. Gene 179: 195-198. https://doi.org/10.1016/s0378-1119(96)00325-3

Kieleczawa J, Dunn JJ, Studier FW (1992) DNA sequencing by primer walking with strings of contiguous hexamers. Science 258: 1787 1791. https://doi.org/10.1126/science.1465615

Kim SC, Podhajska AJ, Szybalski W (1988) Cleaving DNA at any predetermined site with adapter-primers and class-IIS restriction enzymes. Science 240: 504-506. https://doi.org/10.1126/science. 2833816

Lashkari DA, Hunicke-Smith SP, Norgren RM, Davis RW, Brennan T (1995) An automated multiplex oligonucleotide synthesizer: development of high-throughput, low-cost DNA synthesis. Proc Natl Acad Sci U S A 92: 7912-7915. https://doi.org/10.1073/pnas.92.17.7912

Lee JH, O’Sullivan DJ (2006) Sequence analysis of two cryptic plasmids from Bifidobacterium longum DJO10A and construction of a shuttle cloning vector. Appl Environ Microbiol 72: 527-535. https:// doi.org/10.1128/AEM.72.1.527-535.2006

Lee H, Kim KN, Kee Chae Y (2007) Reevaluating the capability of Taq DNA polymerase: long PCR amplification. Protein Pept Lett 14: 1-3. https://doi.org/10.2174/092986607780363934

Lohdi MA, McCombie WR (1996) High-quality automated DNA sequencing primed with hexamer strings. Genome Res 6: 10-18. https://doi.org/10.1101/gr.6.1.10

Nakonieczna J, Kaczorowski T, Obarska-Kosinska A, Bujnicki JM (2009) Functional analysis of MmeI from methanol utilizer Methylophilus methylotrophus, a subtype IIC restriction-modification enzyme related to typeI enzymes. Appl Environ Microbiol 75: 212-223. https://doi.org/10.1128/AEM.01322-08

Podhajska AJ, Szybalski W (1985) Conversion of the FokI endonuclease to a universal restriction enzyme: cleavage of phage M13mp7 DNA at predetermined sites. Gene 40: 175-182. https://doi. org/10.1016/0378-1119(85)90040-x

Posfai G, Szybalski W (1988) A simple method for locating methylated bases in DNA, as applied to detect asymmetric methylation by M.FokI. Gene 69: 147-151. https://doi.org/10.1016/0378$1119(88) 90388-5$

Raja MC, Zevin-Sonkin D, Shvartzburd J, Kotler L, Ulanovsky L (1997) DNA sequencing with modular primers using a two-step protocol with theromostable polymerase at the second step. BioTechniques 23: 362-368. https://doi.org/10.2144/97233bm02

Rosenthal A, Jones DSC (1990) Genomic walking and sequencing by oligo-cassette mediated polymerase chain reaction. Nucl Acids Res 18: 3095-3096. https://doi.org/10.1093/nar/18.10.3095

Sambrook J, Fritsch EF, Maniatis T (1989) Molecular Cloning: A Laboratory Manual, 2nd edn. Cold Spring Harbor Laboratory, Cold Spring Harbor, NY

Sanghvi YS, Schulte M (2004) Therapeutic oligonucleotides: the stateof-the-art in purification technologies. Curr Opin Drug Discov Dev 7: $765-776$

Sektas M, Kaczorowski T, Podhajska AJ (1992) Purification and properties of the MboII, a class-IIS restriction endonuclease. Nucl Acids Res 20: 433-438. https://doi.org/10.1093/nar/20.3.433

Sektas M, Kaczorowski T, Podhajska AJ (1995) Interaction of the MboII restriction endonuclease with DNA. Gene 157: 181-185. https://doi.org/10.1016/0378-1119(94)00742-b

Skowron P, Kaczorowski T, Tucholski J, Podhajska AJ (1993) Atypical DNA-binding properties of class-IIS restriction-endonucleases: evidence for recognition of the cognate sequence by a FokI monomer. Gene 125: 1-10. https://doi.org/10.1016/0378-1119(93)90738-o 
Stefanska A, Kaczorowska AK, Plotka M, Fridjonsson OH, Hreggvidsson GO, Hjorleifsdottir S, Kristjansson JK, Dabrowski S, Kaczorowski T (2014) Discovery and characterization of RecA protein of thermophilic bacterium Thermus thermophilus MAT72 phage Tt72 thaqt increases specificity of a PCR-based DNA amplification. I Biotechnol 182-183: 1-10. https://doi.org/10.1016/j.jbiotec.2014.04.015

Stefanska A, Gaffke L, Kaczorowska AK, Plotka M, Dabrowski S, Kaczorowski T (2016) Highly thermostable RadA protein from the archeon Pyrococcus woesei enhances specificity of simplex and multiplex PCR assays. J Appl Genet 57: 239-249. https://doi. org/10.1007/s13353-015-0314-5

Strauss EC, Kobori JA, Siu G, Hood LE (1986) Specific-primer-directed DNA sequencing. Anal Biochem 154: 353-360. https://doi. org/10.1016/0003-2697(86)90536-1

Szybalski W (1985) Universal restriction endonucleases: designing novel cleavage specificities by combining adapter oligodeoxynucleotide and enzyme moieties. Gene 40: 169-173. https://doi.org/10.1016/03781119(85)90039-3
Szybalski W (1990) Proposal for sequencing DNA using ligation of hexamers to generate sequential elongation primers (SPEL-6). Gene 90: 177-178. https://doi.org/10.1016/0378-1119(90)90458-4

Szybalski W, Kim SC, Hasan N, Podhajska AJ (1991) Class-IIS restriction enzymes - a review. Gene 100: 13-26. https://doi. org/10.1016/0378-1119(91)90345-c

Tucholski J, Skowron PM, Podhajska AJ (1995) MmeI, a class-IIS restriction endonuclease: purification and characterization. Gene 157: 87-92. https://doi.org/10.1016/0378-1119(94)00787-s

Unrau P, Deugau KV (1994) Non-cloning amplification of specific DNA fragments from whole genomic DNA digests using DNA' indexers'. Gene 145: 163-169. https://doi.org/10.1016/03781119(94)90001-9

Velculescu VE, Zhang L, Vogelstein B, Kinzler KW (1995) Serial analysis of gene expression. Science 270: 484-487. https://doi. org/10.1126/science. 270.5235 .484 